日耳鼻 104：1119-1125，2001

$\begin{array}{cc}\text { 宇野 } & \text { 敦彦*,** } \\ \text { 長井 } & \text { 美樹* } \\ \text { 坂田 } & \text { 義治* } \\ \text { 森脇 } & \text { 計博* } \\ \text { 加藤 } & \text { 崇* }\end{array}$

*市立吹田市民病院耳鼻咽喉科

**大阪大学大学院医学研究科

耳鼻咽喉科

\section{市中病院耳鼻咽喉科における最近のめまい統計}

1999年 4 月より 2000 年12月の 1 年 9 力月間に市立吹田市民病院耳鼾咽喉科を受 診しためまい症例1007例について, 市中病院におけるめまい症例の現状として, その疾患内訳を示した。対象症例は, 良性発作性頭位めまい症 (BPPV), BPPV 疑い, BPPV 以外の末佾性前庭障害, 未梢前庭性以外の疾患, 未診断の 5 群に分

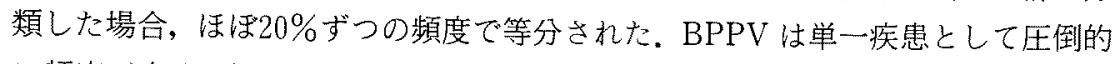
に頻度が高く，疑い例を含めると全体の約 $40 \%$ を占めた。穴の他の末梢性前庭障 害では,メニエール病が最も多く, 疑い例を含めて全体の約 $8 \%$ であった。市中 病院ではめまい急性期の症例が多く，その鑑別が市中病院の重要な役割である. まず頻度の点から BPPV, BPPV 以外の末梢性前庭障害，その他の疾患の順に鑑 別診断を行うことが効率的と考えた。急性期であれば BPPVは誘発される眼振に より診断され，他の末梢性前庭障害についても眼振所見によって診断される率が 高い. 一方で，重症化する可能性のある脳血管障害・心循環器系障害等の鑑別も 重要であり,まれでない.急性期の鑑別で特に重要な脳出血・梗塞は対象症例の $1.6 \%$ であった，脳占拠性病変は $1.2 \%$ であった。

\section{キーワード：めまい，臨床統計，良性発作性頭位めまい症，メ二エール病，} 中枢性めまい
はじめに

‘めまいは外来の主訴として最も多いものの一つであ ク，その原因疾患は多岐にわたる.鑑別診断のためには， 耳内所見と前庭機能の理解が不可欠であり耳鼻咽喉科の 果たす役割は大きい. 特に一次二次救急に対応する市中 病院にあっては，急性期のめまい診断を効率的に進める ことが望まれる，そのためには疾患頻度を念頭におく必 要があるが，これまでに報告されためまい統計は，大学 病院のめまい外来受診例や，十分な平衡機能検查を経た 例のみの結果などが多く，市中病院の現状を反映する報 告は限られている(1)-6). 本稿では, 当科で最近 1 年 9 力月 間に経験しためまい症例について，市中病院でのめまい 疾患の現状として報告する。

当院は地域の一次二次診療を担う計 431 床の総合病院 であり, 時間外救急は内科, 外科系, 小児科の 24 時間体 制がとられ，脳神経外科緊急手術の体制もある。一般診 療時間中のめまい患者は本人の希望がなければ耳鼻咽喉 科で, 時間外夜間は内科救急外来でまず対応する. 救急 外来のみ受診し, 当院への再診がなかった患者を除いて,
めまい患者は原則的に一度は耳鼻咽喉科を受診すること としている.

従来のめまい統計では，「その他の‥」など診断詳細の 不明な項目が多くあった。めまいには単一の病態として 診断され難く，殓断基準に合わない場合も多いことを示 すと思われる.しかし，市中病院では大学などの専門外 来に比べ急性期を診察できる機会が多く，主訴となるめ まいの状態を把握しやすい.こういった利点を生かし， 詳細不明な部分をできるだけ減らすため, 初診時からあ らかじめ決めた診断項目に分類していき，経過により分 類しなおす方針で統計を行った。

\section{対象と方法}

平成11年 4 月 1 日より平成12年12月末までの 1 年 9 力 月間に，市立吹田市民病院耳鼻咽喉科一般外来招よびめ まい外来を初診・紹介初訬した1007例を対象とした。男 女比，年齢分布を図 1に示す.男女比は約 $1 ： 2$ であり， 61-70歳代にピークがあった。これらの症例が初めに受 診した診療科を図 2 に示す。当科を初診した例が401例 


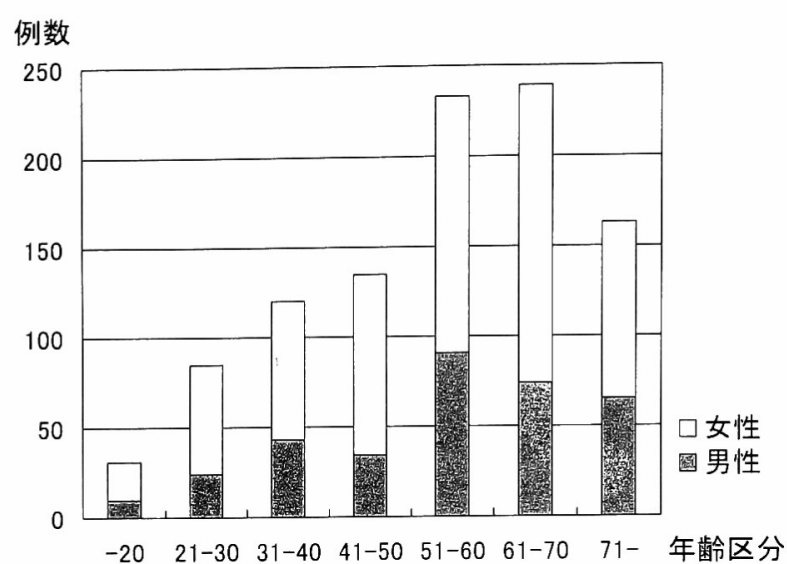

図 1 全めまい症例の年齡分布・男女比

$(39 \%)$ ，それ以外は，院内他科・他の医療機関を受診し た後に，当科を受診した。

当科での診察は，めまい問診表の記載，一般耳鼻咽喉 検査, 眼球運動検查, 自発・注視・頭位 - 頭位変換眼振 頭振後眼振検査，体平衡検査，血圧や脈拍など一般内科 的検査, 一般神経学的検査, 聴力検査, 耳レントゲン検 査を基本とし，血液検査，血圧シェロング検査，ENG， 温度刺激検査, グリセロール試験, $\mathrm{ABR}$, 頸椎レントゲ ン検査, 心電図, MRI・MRA 検査等を疾患に応じて追加 した. 眼振検査は，ほとんどの例に赤外線フレンツェル 眼鏡を用いた。中枢疾患の疑われる例はもちろん，急性 や進行性の難聴, 前庭機能低下がみられた症例には原則 的に MRI を施行した。

めまい症例はすべて初診時に登録用紙に登録し，良性 発作性頭位也まい症 (BPPV), BPPV 疑い, BPPV 以外 の末梢性前庭障害，末梢前庭性以外の疾患，未診断の 5 群の診断項目に分類, 検査治療の経過により毎回分類し なおした。診断は，日本平衡神経科学会（現：日本めま い平衡医学会）めまい診断基準化のための資料一1987年 めまい診断基準化委員会答申書一7)(以降，日本めまい平 衡医学会の基準）を基本とし，診断基準に網羅されない 病態や準じていない点は, 以下のように分類した. BPPV は先に報告したように ${ }^{8)}$ ，眼振の誘発から診断した確実 例と，眼振はなかったが問診と鑑別から診断した疑い例 (BPPV 疑い) に区別した。また眼振の誘発される様式に より，後半規管型 (P-BPPV) と水平半規管型 $(\mathrm{H}-$ $\mathrm{BPPV})$, 前半規管型 $(\mathrm{A}-\mathrm{BPPV})^{9110)}$ に区別した。さらに, H-BPPV は方向交代性下行性（向地性）と上行性（背地 性）の眼振を区別した.メニエール病様のめまい発作を 繰り返し, 蝸牛症状を伴わない例は前庭型メニエール病 とした ${ }^{7111}$. この内, めまい発作時の眼振経過が確認でき ていない例は, 前庭型メニエール病疑い例とした。診断

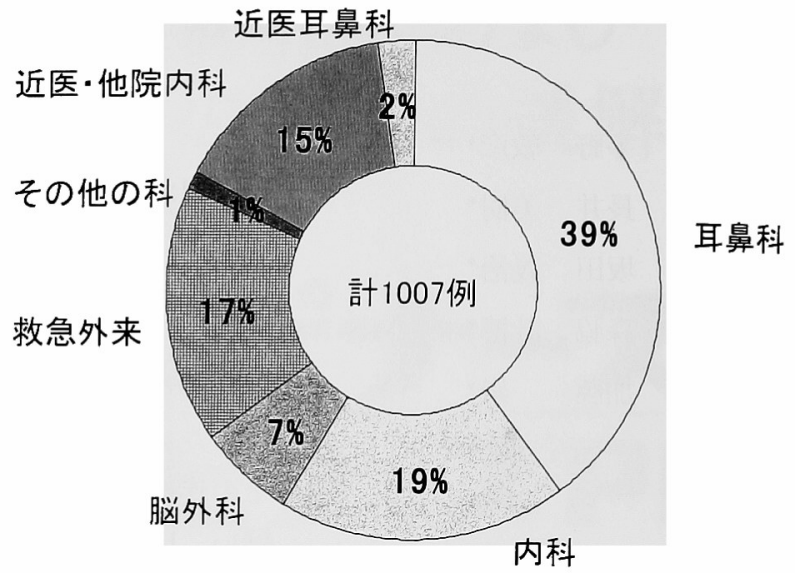

図 2 めまいの初診診療科

名のつかない末梢前庭性めまい症例は，その他の末梢性 前庭障害とし，症状の経過別に細分類した．末梢前庭性 以外の疾患は脳占拠性病変, 脳血管障害, 心循環器系障 害, 心因性，その他と分類し，さらに診断名がつけられ る症例はそれを記載した。

\section{結 果}

1. めまい症例の分類

図 3 に示すように, 症例全体は BPPV, BPPV 疑い, BPPV 以外の末梢性前庭障害, 末梢前庭性以外の疾患,

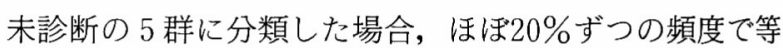
分された. BPPV は単一疾患として圧倒的に多く235例 $(23 \%)$ を占め, 疑い例まで含めると全体の $41 \%$ を占めた。

2. BPPV の細分類 (図 4)

頭位変換眼振検査で回旋成分と上眼瞼向き垂直成分の 混合性眼振が誘発された P-BPPV が158例（BPPVの $67 \%)$, 頭位眼振検査において側臥位で水平成分が中心の 眼振が誘発された H-BPPV は69例（BPPVの29\%） あった。 6 例には P-BPPV から H-BPPV あるいはその 逆への移行がみられた，また，頭位変換眼振検査で回旋 成分と下眼瞼向き垂直成分の混合性眼振が誘発された A-BPPV は 2 例（BPPV の0.8\%）であった，方向交代 性下向性眼振のみられた H-BPPV は47例 (H-BPPVの $68 \%)$, 方向交代性上行性が16例あった。それらの移行が 6 例にみられた。

3. BPPV 以外の末梢性前庭障害（表 1)

BPPV 以外の末梢性前庭障害では，メニエール病の頻 度が最も高かった。メニエール病確実例の59例は，ほほ 全例に発作期あるいは発作後早期の眼振を確認できた。 疑い例までを含めると，メニエール病はめまい全体の約 $8 \%$ を占めた。日本めまい平衡医学会の基準でメニエー ル疑いとした例も，厚生省特定疾患「メニエール病」調 


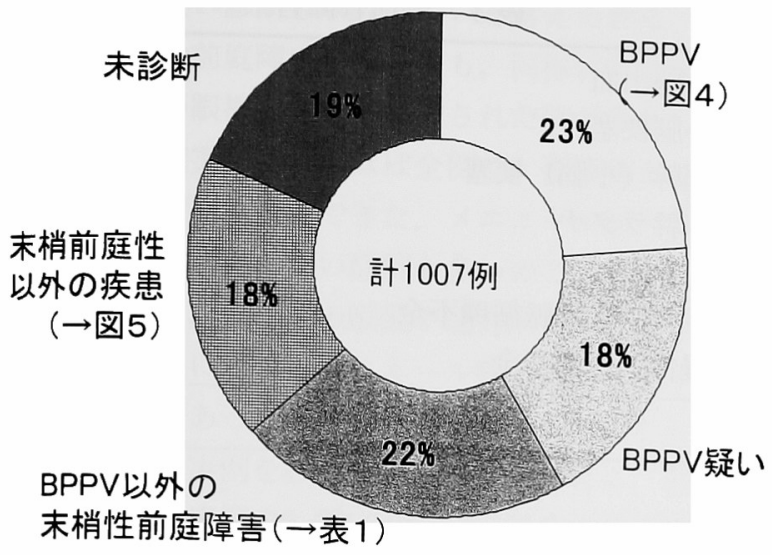

図 3 全めまい症例1007例の分類

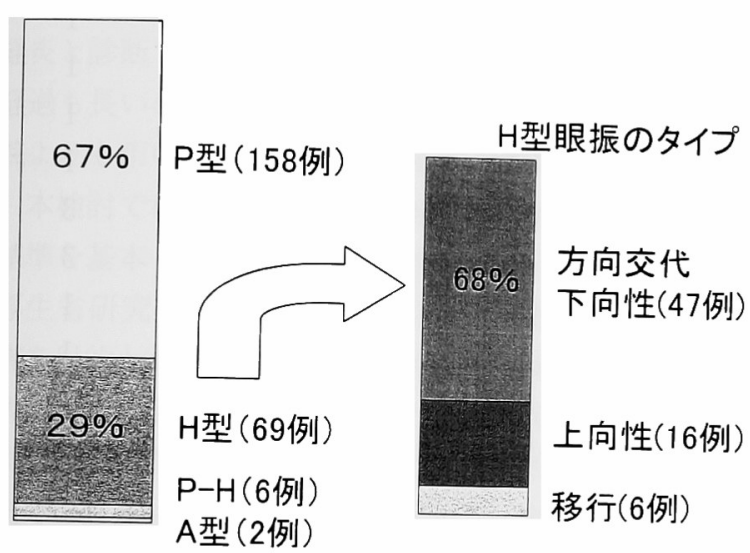

図 4 眼振所見による BPPV の細分類

$\mathrm{P}$ 型：後半規管型 BPPV, H型：水平半規 管型 BPPV, P-H : P 型と H型を移行した 例, A 型 : 前半規管型 BPPV

査研究班の診断の手引き ${ }^{22)}$ (厚生省研究班の基準)ではメ ニエール病確実例にあたり, American Academy of Otolaryngology-Head and Neck Surgery Foundation (AAO-HNS)のメニエール病診断基準 ${ }^{13)}$ では, 聴力障害 が確認できればDifinite Meniere's diseaseに分類され る.

前庭型メニエール病の13例は発作期の眼振を確認し, 経過と合わせて診断した．疑い例を含めて24例あった。 ただし，これらは厚生省研究班の基準 ${ }^{12)}$ ではメニエール 病疑い例に含まれ, AAO-HNS の基準13) では Possible Meniere's disease に分類される.

前庭神経炎の27例には, 病歴からの疑い診断は含めて いない ${ }^{7114)}$. めまいを伴う突発性難聴13例は, 主訴として めまいと難聴を訴えた。急性中耳炎, 慢性中耳炎急性増 悪, 真珠腫性中耳炎, 中耳炎術後耳による中耳炎に関連 しためまいは計10例，全体の $1 \%$ であった。日本めまい
表 1 BPPV 以外の末梢性前庭障害

\begin{tabular}{lc} 
メニエール病 確実 & 59 \\
メニエール病 ほぼ確実／疑い & 18 \\
前庭型メニエール病 & 13 \\
前庭型メニエール病 疑い & 11 \\
遅発性内リンパ水腫 & 3 \\
前庭神経炎 & 27 \\
めまいを伴う突発性難聴 & 13 \\
中耳炎に関連するめまい & 10 \\
ムンプスによる内耳障害 & 2 \\
ハント症候群 & 1 \\
内耳振盪症 & 1 \\
その他 (この内訳は本文中) & 60 \\
\multicolumn{2}{c}{ 計 }
\end{tabular}

平衡医学会の基準7 では,「慢性中耳炎由来の内耳障害」 とされるが, 本10例中の 2 例は急性中耳炎に伴った。ム ンプス難聴の 2 例, ハント症候群の 1 例, 内耳振盪の 1

例は，いずれも健側向き自発眼振を認めた。

その他の末梢性前庭障害とした60例は, 症状から以下 の 4 つに細分類した．軽度難聴や耳鳴りを伴う初回回転 性めまいが17例あった．繰り返す発作ではないので，め まい平衡医学会の基準7ではメニエール病に入らない が, 経過によりメニエール病と診断される可能性がある. AAO-HNS の基準 ${ }^{13)}$ では, Probable Meniere’s disease に分類される. 初診時には眼振があったが，温度眼振反 応の低下は確認できなかった初回めまい例が17例あっ た. 問診上数時間以上続く回転性めまいか, 温度眼振反 応の低下により末梢前庭性めまいの疑われた例が24例 あった．両側の進行性感音難聴に非回転性めまいを伴っ た例が 2 例あった。

4. 末梢前庭性以外の疾患（図 5 )

脳占拠性疾患が 12 例あり全体の約 $1 \%$ を占めた。その 詳細は, 表 2 に示した. 脳血管障害が関与するめまい症 例は71例, 全めまいの約 $7 \%$ であった ${ }^{15)}$ (表 3 ).脳出血・ 梗塞例では, 歯状核付近の比較的小さな小脳出血をみた 1 例, 小脳梗塞が 7 例, 脳幹 (一部小脳を含む) 梗塞が 5 例，これとは別に脳幹のラクナ梗塞をみた例が 4 例, の計16例あり，めまい全体の $1.6 \%$ であった. 16例すべて がめまい発症 1 日以内に当院を受診し, その半数は救急 外来を受診した。17例を椎骨脳底動脈循環不全症 (VBI) と診断した. 反復するめまい以外に, 他の脳幹領域の神 経症状 (一過性の顔のしびれや構音障害, 視野の障害等), 頸部運動刺激による異常所見, 中枢性を示唆する異常眼 球運動所見，MRA や血管造影で椎骨脳底動脈系血管の 明らかな狭窄や閉塞所見のいずれかが認められた場合に 


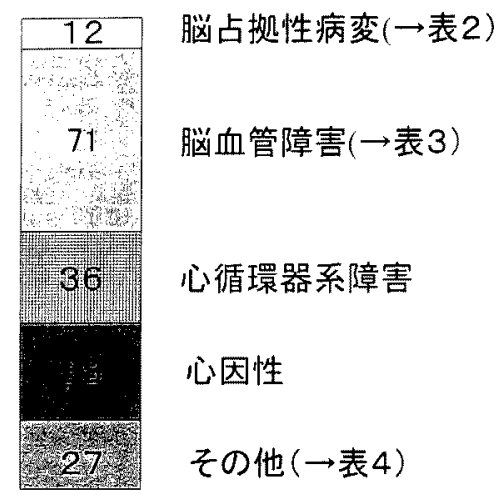

図 5 末梢前庭性以外の疾患

表 2 脳占拠性病変

\begin{tabular}{|c|c|}
\hline 聴神経腫曒 & 4 \\
\hline 転移性小脳腫漡 & 2 \\
\hline 神経膠腫（延䯣一小脳 各 1） & 2 \\
\hline 三叉神経鞘腫 & 1 \\
\hline 髄膜種（後頭蓋窩） & 1 \\
\hline 小脳 AVM & 1 \\
\hline 小脳橋角部のう胞 & 1 \\
\hline 計 & 12例 \\
\hline
\end{tabular}

診断した ${ }^{716)(7)}$. 椎骨脳底動脈系の局所神経症状や所見が ない高龄者の動摇性めまいの38例は，細動脈硬化を基盤 とし慢性かつびまん性に脳血流が低下している病態とし て慢性脳循㻴不全と診断した ${ }^{18)}$.

心循授器系障害は, 不整脈, 心不全, 血圧異常, 起立 性調節障害, 血管迷走神経反射, 負血などによるめまい 症例である。合計で36例，全体の3.6\%であった。

心因性めまいは，平衡障害の所見がなく，精神神経科 的にも神経症や精神病と診断されている例, あるいは抗 不安薬や抗うつ薬の著効例など38例であった。

その他の疾患としてまれな疾患や病態峙 4 に示し た.

\section{5. 未診断}

めまい全体の19\%(187例) は未診断であった。このう ち51例は回転性めまいの訴えがあり，53例には一側難聴 や進行性難聴, 眼球運動の異常, 脳梗塞の既往, MRA上 での血管狭窄像，血圧異常など何らかの所見があったが 診断に至らなかった。

\section{考察}

めまい症例全体をみると, BPPVが23\%，疑い例まで 含めると当科に受診した $41 \%$ BPPVであり, 過去の他 施設の報告と比べて BPPV の頻度がかなり高い(1)-6119!.
表 3 脳血管障害

\begin{tabular}{ll}
\hline 小脳出血 & 1 \\
小脳梗塞 & 7 \\
脳幹 (小脳) 梗塞 & 4 \\
脳幹ラクナ & 4 \\
& \\
椎骨脳底動脈循環不全 & 17 \\
慢性脳循環不全 & 38 \\
\hline & 計 \\
\hline
\end{tabular}

表 4 その他の疾患

\begin{tabular}{|c|c|}
\hline 冾䯣小脳変性症 & 3 \\
\hline 進行性核上性麻渒 & 1 \\
\hline 亜急性小脳変性症 & 1 \\
\hline 多発性硬化症 & 1 \\
\hline 小脳脳幹脳炎 & 1 \\
\hline 䯣膜炎 & 1 \\
\hline 糖尿病性末梢神経障害 & 3 \\
\hline 片頭痛に伴うめまい & 3 \\
\hline 顔面痙攣に伴うめまい & 1 \\
\hline 甲状腺機能六進症 & 1 \\
\hline 白血病による貧血 & 1 \\
\hline 頭部外傷後異常眼球運動 & 1 \\
\hline てんかん & 1 \\
\hline 頭痛 & 1 \\
\hline 発熱 & 1 \\
\hline 睡眠時無呼吸症 & 1 \\
\hline 乗り物酔い & 2 \\
\hline 視覚依存性めまい & 3 \\
\hline 計 & 28例 \\
\hline
\end{tabular}

我々は1999年度 1 年間に初診した BPPVの臨床像につ いてすでに報告したが，この時点での結果と今回 1 年 9 力月間でのめまい症例全体に占める割合(図 3), 眼振加 らみたタイプ別頻度（図 4) はそれぞれほぼ同様であっ だ).我々の検討では H-BPPV を含めており, 過去のPBPPVを中心とした検討より BPPVの頻度が高くな る. H-BPPVを含めた最近の佐藤らの報告 ${ }^{20)}$ では,めま い初診の $27.5 \%$ BPPV あるいは BPPV 疑い例とさ れ，我々の結果に比較的近い。 また，BPPV は自然寛解 のみられる疾患であり，二次三次医療施設よりも市中病 院での頻度が高い疾患と考えられる. 山中らの市中病院 での統計4でも，BPPV あるいは末㭇性頭位性めまい症 がめまい全体の $10.4 \%$, 同時期の大学病院などの報告 よりも頻度が高い. 市中病院には発症早期に受診する例 が多く ${ }^{8)}$, 誘発される眼振から診断される例が多くなり, 
問診からも疑い診断もされやすいと考えられる. 他の末梢性前庭障害についても，同様に急性期の症例 が多く，その眼振所見から診断された例が多かった。メ ニエール病確実例 59 例のほ注全例で, 発作期あるいは発 作後早期の眼振を確認できた.メニエール病の初期では 間歇期に異常所見のない症例も多いので, 検查からの確 実例診断には，発作期の眼振や恥力所見が重要となる. 全めまい症例に対するメニエール病の頻度は過去の報告 とほほ同様であったが，発作期を診ることでむしろ市中 病院の方が確実例を診断しやすいと思われる。前庭神経 炎は全めまい症例の2.7\%であった。厚生省前庭機能暴常 調査研究班での診断基準 ${ }^{21)}$ では, 発作期の確認は要求さ れていないが, 日本めまい平衡医学会の基準では, 発作 期の眼振と温度眼振反応の低下を確認しなければ前庭神 経炎と診断できない. 前庭神経炎のめまいは症状が強く 経過も長いので，入院治療を要する場合が多く，大学病 院よりも市中病院で診断される例が多いと思われる.

本検討では，末梢性めまいを日本めまい平衡医学会の 基準を基本として，細かく分類した。メニエール病など 厚生省研究班の基準 ${ }^{12211}$ は診療科を超えて広い疫学調 査を目的としているが，日本めまい平衡医学会の基準は 専門科での臨床的診断を目的とし，検査からの診断を重 視し疑い例と確実例を区別している。我々も，耳鼻咽喉 科での診療において，少なくとも末梢性めまいに関して 㹥,細かく症例を区別しておくことが必要と考えている. 臨床病態の揃った症例を細汃く分類しておくことで, 治 療効果の比較や，いまだ十分に明らかでない病態の解明 がなされると思われる。

末梢前庭性以外の疾患は全めまい症例の18\%であっ た. 本検討では, 当院を受診しためまい症例の全体像に 近づけたいとの考えで，他科領域の疾患であっても原則 的に当科を受診してもらった。それでも，他科からの紹 介例は，めまいの定義にもかか力る問題で，耳鼻科的め まい，回転性めまい例に偏重する傾向は否定できない。 より広くめまいを考えると，末梢前庭性以外の疾患は もっと多い可能性がある. 本検討中で，急性期めまい診 断の重要な鑑別診断となる脳出血・梗塞は全体の $1.6 \%$ あった。これらの症例は，すべて発症 1 日以内に当院を 受診しており，急性期症例に対応する場合はもつと頻度 が高いと考えて臨む必要がある.小脳出血の 1 例は, 緊 急の単純 CT で診断されたが，他の脳梗塞例は緊急の CTでは画像診断できておらず, 神経学的理学所見が重 要であった。脳幹を含む梗塞の場合は，感覚障害や他の 脳神経障害が同時にみられる場合が多く，眼球運動も回 旋斜行など明らかな中枢性眼振がみられる場合が多かつ た。しかし，めまいを主訴とした小脳梗塞には，急性期
でも四肢の小脳徵候が明らかでない例がある。眼球運動 の異常や体幹失調の有無は重要な所見だが，特に一側前 庭障害の上うな水平性眼振のみら机た例では, 体幹失調 や嘔吐が強くても, 末枌障害との鑑別は難しかった，急 性期のめまい症例で他の神経学的所見に乏しい場合で も, 体幹失調・嘔吐などの症状が強い例は，入院により 経過をみる必要があると考えている。また画像診断では MRIが緊急で撮影できる体制が望まれる。

血管障害の検出やそのリスクファクターの検索のた め, あるいは失神様めまいの原因検索のために, 循環器 系の簡単な検查は有用であった。不整脈や心頸部雑音が 約 $1 \%$ の症例にみられた。循環器内科など他科との連携 は当然重要であるが，まず診察の段階で心循環器系の異 常を念頭に置く必要がある。末梢前庭性以外の疾患には， その他に教科舂的にみられるような様々な疾患, 病態が みられた（表 4)。それぞれ頻度が高いとは言えないが， 1000例程度の症例のなかに含まれるという認識は必要で ある。

このような多岐にわたる原因疾患の中から診断をすす める第一歩として, 疾患の頻度と重篤な疾患の種類とを 考える必要がある. 頻度の点から，まず，1） BPPV，2） BPPV 以外の末梢性前庭障害，3）その他の疾患，に分 類することを考えている. BPPV は問診と頭位変換眼振 検査でほほ診断できる。末梢性前庭障害も問診から類推 され，特に急性期であれば眼振検査でかなり診断に近づ く，本検討の頻度では，ここまでで約 6 割の症例が含ま れることになる，それ以外仙，末梢前庭性以外の疾患が 疑われる。ここでは重篤な経過をとる可能性のある疾患 の鑑別が重要となり，急性期では脳血管障害，頭蓋内炎 症性疾患, 心循環器障害, 亚急性期以降では脳占拠性病 変が代表的である。これらの鑑別を念頭におき，急性期 のめまい症例ではバイタルサインの確認, 耳鼻咽喉診察 と同時に脳神経症状を，眼球運動・眼振検查と同時に髄 膜刺激症状や钼部運動の影響，心頸部雑音などの恥診と 脈拍左右差不整の有無, 四肢の小脳徵候・感覚運動, 体 平衡検査まで一連の検査がまず必要と考えている．脳血 管障害と脳占趑性病変の診断には脳 MRI が必須となる が，末梢性めまいの疑い例にどこまで脳MRIを行うか は議論がある22).当科では BPPV 典型例などには行わな いが，難聴や前庭機能低下の検査所見が得られた例には 積極的にMRIを施行した．脳占拠性病変は全めまい中 の1.2\%にあった。

本検討には，疾患頻度を調査する目的と同時に，でき るだけ診断をつけて治療にあたりたいという考えがあっ たが，それでも全体の19\%が末診断となった．今後の経 過により診断される例もあると思われるが、これまでの 
報告でも，めまい症とされる例は近年な抢多く存在する と指摘される ${ }^{466}$. 一つには症状のあるときに診察できて いないことがある。小回りのきく市中病院にあっては, より細かい経過観察や救急対応による診断向上が望まれ る。また，何らかの所見があっても診断し難い例がある ことは，めまいの原因となる病態が単一でないことや， 診断基準の狭間にある病態の可能性, 例えば耳石機能障 害など内耳部分障害の検出が一般的にはなされない点な どが考えられる．この点は大学病院などの専門外来と協 力のうえ，診断向上させるべき課題と考えている．さら に, 心因性めまいが約 $4 \%$ にみられたこととも関連して, 脳がめまい’と感じるメカニズムについても理解が必要 と考えている.

\section{参考文献}

1) 佐野光仁, 津田守, 後藤和彦, 松永亨, 松永喬: 当科めまい外来の受診動態一昭和 52,53 年度を中心とし て一。耳鼻臨床 73:264-269，1980。

2）秋定健，山本英一，河田信，佐藤幸弘，中川の多 子，他：当科におけるめまい症例の統計的観察．耳鼻 $35: 36-41,1989$.

3）星野功，德增厚二，藤野明人，長沼英明，新井基洋， 他: 北里大学耳鼻呕喉科めまい外来 25 年間の患者推移. Equilibrium Res 56 : 274-283, 1997.

4）山中泰輝，岡亮，大坂正浩，佐伯和夫，和久田幸之 助，他：当科14年間のめまい症例の統計的観察.耳鼻臨 床 $89: 1051-1060,1996$.

5）嘉村恵理子, 相原康孝，山口 潤，八木聰明：めまい外 来 1 万例の統計的検討. 耳鼻頭頸 71: 901-906, 1999.

6）小松崎安美, 神永千織, 釣巻周子, 石田孝, 三好俊 二,他：当教室15年間のめまい患者の統計的観察，耳鼻 臨床 補 59:7-13，1992。

7) 小松崎 篤、二木 隆、原田康夫，朴沢二郎，石井哲 夫，他：めまい診断基準化のための資料一1987年めまい の診断基準化委員会答申書一. Equilibrium Res 47 : 245-273, 1988.

8）宇野敦彦，森脇計博，加藤 崇，長井美樹，坂田義治： 良性発作性頭位性めまい症の臨床検討，日耳鼻 104 ： 9-16, 2001.

9) Herdman SJ, Tusa RJ : Complication of the canalith repositioning procedure. Arch Otolaryngol Head Neck Surg 122: 281-286, 1996.
10) Honrubia, V, Baloh WB, Harris MR, Jacobson KM: Paroxysmal potitional vertigo syndrome. Am J Otol $20: 465-470,1999$.

11）池田元久, 渡辺勈: メニエール病疑い例の検討. Equilibrium Res 56 : 258-267, 1997.

12）渡辺 勈: 厚生省研究班のメ二エール病診断基準につい て. 耳鼻跕床 69:301-303，1976.

13) Committee on Hearing and Equilibrium: Committee on hearing and equilibrium guidelines for the diagnosis and evaluation of therapy in Meniere's disease. Otolaryngol Head Neck Surg 113: 181-185, 1995.

14）武田憲昭, 肥塚 泉, 河野幹子, 西池季隆, 久保武, 他：前庭神経炎の診断および治療における問題点一突発 性めまい症例の臨床検討からの考察一。日耳鼻 98： 951-958, 1995.

15) NIDS Committee: Classification of cerebrovascular diseases III. Stroke 21: 637-676, 1990.

16）松永 喬：形態学的坊よび機能的画像診断一椎骨脳底動 脈循環不全一。目鼻 $100: 798-801 ， 1997$.

17) 寺尾 章: 椎骨脳底動脈循環不全症. 別冊日本臨床 $26: 277-279,2000$.

18）平井俊策：慢性脳循環不全症. Annual Review 神経 1995: 134-138，1995

19）佐久野利春，中島成人，重野浩一郎，隅上秀伯：良性頭 位性めまい症の臨床的観察一最近10年間の統計を中心に 一. Equilibrium Res 46: 267-271, 1987.

20）佐藤成樹，肥塚 泉，黒田寿史，釰持 睦，大橋 徹、 他：疑い例を含む良性発作性頭位眩軍症の診断と治療。 Equilibrium Res 60:29-36, 2001.

21）渡辺 勈, 水越鉄理, 大久保 仁, 池田元久, 渡辺行 雄：前庭機能異常に関する疫学調查報告：個人調查票集 計を中心に。耳鼻臨床 67:2426-2457，1983.

22）播摩谷 敦, 水見徹夫, 原㴊保明, 朝倉光司, 形浦昭 克: 小脳橋角部腫埸の臨床的検討. 耳鼻臨床 $92: 587-$ $593,1999$.

当科めまい診療を支えていただく当院内科・脳神経外科・放 射線科各先生方, 本稿をご指導いただいた大阪大学耳鼻咽喉 科久保武教授, 徳島大学耳鼻咽喉科武田憲昭教授に深く感謝 いたします。

(2001年 4 月 3 日受稿 2001 年 8 月 2 日受理)

別刷請求先 †565-0871 吹田市山田丘2-2 大阪大学大学院医学研究科耳鼻咽堠科 宇野敦彦 


\title{
Statistical Observation of Vertigo and Dizziness Patients
}

\author{
Atsuhiko Uno, M.D.***, Miki Nagai, M.D.*, Yoshiharu Sakata, M.D.* \\ Kazuhiro Moriwaki, M.D.* and Takashi Kato, M.D.* \\ *Department of Otolaryngology, Suita Municipal Hospital, Osaka \\ **Department of Otolaryngology, Osaka University Graduate School of Medicine, Osaka
}

Subjects visiting the Department of Otolaryngology at Suita Municipal Hospital reporting vertigo or dizziness numbered 664 women and 343 men from April 1999 to December 2000. As a city hospital, we play an important role in the diagnosis and treatment of acute vertigo or dizziness. The frequency of diagnosis of these cases was divided almost equally into 5 groups: (1) benign paroxysmal positional vertigo (BPPV) $23 \%$; (2) suspected BPPV, 18\%; (3) peripheral vestibular disorders other than BPPV, $22 \%$; (4) disorders other than peripheral origin, $18 \%$; and (5) undiagnosed, 19\%. Based on our results, BPPV, other peripheral vestibular disorders, and disorders of other origins should be differentiated from the first screening. BPPV was most frequent and diagnosed by typical positioning nystagmus. Many other peripheral vestibular disorders were accompanied by nystagmus. It is also important to differentiate serious illnesses such as cerebrovascular disease (7\%), space-occupying lesions in the posterior fossa $(1.2 \%)$, and cardio-circulatory disease $(3.6 \%)$.

Keywords : vertigo, clinical statistics, benign paroxysmal positional vertigo, Meniere's disease

J Otolaryngol Jpn 104: 1119-1125, 2001 